\title{
PENGARUH ANALISIS 5C TERHADAP KEBIJAKAN KREDIT PADA KPN WERDHI YASA
}

\author{
Fredy Jehantana \\ Jurusan Akuntansi Program Diploma III, \\ Universitas Pendidikan Ganesha,Singaraja \\ fredyjehantana.96@gmail.com
}

\begin{abstract}
Abstrak
Penelitian ini bertujuan untuk mengetahui pengaruh analisis $5 \mathrm{C}$ terhadap kebijakan kredit pada KPN Werdhi Yasa. Subjek dalam penelitian ini adalah KPN Werdhi Yasa. Metode pengumpulan data yang digunakan dalam penelitian ini adalah metode wawancara dan dokumentasi. Data dianalisis menggunakan teknik analisis deskritip kualitatif.

Hasil penelitian ini menunjukkan bahwa analisis $5 \mathrm{C}$ sangat berpengaruh terhadap kebijakan kredit pada KPN Werdhi Yasa. Mengingat analisis 5C memang menjadi faktor yang menentukan pada KPN Werdhi Yasa, mengenai diterima atau ditolaknya permohonan kredit yang diajukan oleh calon debitur.Analisis 5C dimana selain dapat membantu kehati-hatian pada KPN dalam memberikan kredit, juga dapat memberikan cara pada KPN untuk mengetahuui sifat atau watak calon debitur,, kemampuan calon debitur dalam membayar kreditnya, mengetahui kondisi kekeyaan yang dimiliki calon debitur, mengetahui prospek usaha calon debitur kedepannya, dan jaminan yang akan diberikan oleh calon debitur kepada KPN Werdhi Yasa.Prinsip 5C ini dilaksanakan sebelum kredit tersebut disalurkan.
\end{abstract}

Kata Kunci : Analisis 5C, Kebijakan Kredit, dan KPN Werdhi Yasa

\begin{abstract}
This study aims to determine the effect $5 \mathrm{C}$ analysis of the credit policy on KPN Werdhi Yasa. Subjects in this study is KPN Werdhi Yasa. Data collection methods used in this study were interviews and documentation. Data were analyzed using qualitative analysis techniques deskritip.

The results of this study indicate that the $5 \mathrm{C}$ analysis greatly affect the credit policy on KPN Werdhi Yasa. Given the 5C analysis has become a decisive factor in KPN Werdhi Yasa, regarding the acceptance or rejection of credit applications submitted by prospective borrowers. At KPN Werdhi Yasa, $5 \mathrm{C}$ analysis which in addition can help prudence on KPN to provide credit, these principles can also provide a way in KPN to mengetahuui the nature or character of prospective borrowers (character), the ability of potential borrowers to pay credit (capacity), knowing kekeyaan state owned debtor (capital), knowing the future business prospects of potential borrowers (condition of economy), and guarantees to be provided by the debtor to the KPN Werdhi Yasa (collateral). 5C principle was implemented before the loan was disbursed.
\end{abstract}

Keywords : Analysis 5C, Credit Policy, and KPN Werdhi Yasa

\section{Pendahuluan}

Koperasi sebagai lembaga keuangan, dalam kegiatan usahanya sangat diperlukan masyarakat. Kegiatan usaha yang dimaksud dapat berupa pelayanan kredit, kegiatan pemasaran, atau kegiatan lain. Selain itu, koperasi telah menjadi alternatif bagi lembaga usaha lain dalam pemberian kredit atau pinjaman. Pada kondisi ini masyarakat telah merasakan bahwa manfaat dan peran koperasi lebih baik dibandingkan dengan lembaga lain, seperti bank pada umumnya, karena koperasi memiliki tujuan utama yaitu untuk mensejahtrakan anggotannya serta dilihat dari tingkat suku bunga koperasi yang lebih rendah dibandingkan tingkat suku bunga bank. 
Koperasi juga telah menjadi organisasi yang dimiliki oleh anggotanya. Rasa memiliki ini dinilai telah menjadi faktor utama yang menyebabkan koperasi mampu bertahan pada berbagai kondisi sulit, yaitu dengan mengandalkan loyalitas anggota dan kesediaan anggota untuk bersama-sama menghadapi kesulitan tersebut. Koperasi merupakan salah satu lembaga wujud ideal organisasi ekonomi rakyat. Dalam pelaksanaan koperasi memiliki kebijakan dan prinsip tersendiri yaitu kekeluargaan dan gotong royong.

Koperasi di Indonesia lahir secara alami dari masyarakat pada waktu zaman penjajahan. Perkembangan koperasi mulai pesat setelah era kemerdekaan. Perkembangan koperasi di Indonesia mengalami pasang naik dan turun dengan lingkup kegiatan usaha secara menyeluruh yang berbeda-beda dari waktu ke waktu sesuai dengan kemajuan zaman. Pertumbuhan koperasi yang pertama di Indonesia menekankan pada kegiatan simpan pinjam.

Koperasi di Indonesia lahir secara alami dari masyarakat pada waktu zaman penjajahan. Perkembangan koperasi mulai pesat setelah era kemerdekaan. Perkembangan koperasi di Indonesia mengalami pasang naik dan turun dengan lingkup kegiatan usaha secara menyeluruh yang berbeda-beda dari waktu ke waktu sesuai dengan kemajuan zaman. Pertumbuhan koperasi yang pertama di Indonesia menekankan pada kegiatan simpan pinjam. KPN didirikan dengan tujuan untuk meningkatkan taraf hidup pegawai negeri.

KPN juga dapat dijadikan sebagai suatu wadah bagi Pegawai Negeri yang ingin mengembangkan potensi kewirausahaan yang mereka miliki. Dengan adanya KPN diharapkan dapat membantu pegawai negeri dalam meningkatkan taraf hidup pegawai negeri baik berupa kredit pinjaman modal, kredit konsumsi, tabungan dan sebagainya. Dari beberapa jenis usaha yang dilakukan oleh KPN yang menjadi usaha utama adalah pemberian kredit, Pemberian kredit pada KPN sangat sarat akan resiko apabila pihak KPN tidak menganalisis pemberian kredit dari berbagai aspek yang terkait untuk melakukan penilaian, dan dalam pemberian kredit dibutuhkan perhitungan-perhitungan yang mendalam yang meliputi berbagai prinsip, azas, atau persyaratan tertentu.

Salah satu KPN yang ada di Buleleng adalah KPN Werdhi Yasa yang berlokasi di Jalan Bisma No. 8 XX Singaraja. KPN Werdhi Yasa adalah KPN yang memberikan kredit pada anggotanya, dimana sebagian besar anggotanya adalah Pegawai Negeri Sipil (PNS). Dilihat dari jumlah pinjaman yang diberikan mengalami peningkatan dari tahun ke tahun dan ini membuktikan bahwa KPN Werdhi Yasa sudah mendapatkan kepercayaan dari para anggotanya.

Kemudian dari jumlah pinjaman yang terjadi di KPN Werdhi Yasa maka perlu dilakukan analisis supaya dapat meminimalisir terjadinya kredit macet. Didalam pemberian kredit dibutuhkan perhitungan-perhitungan yang mendalam yang meliputi berbagai prinsip, asas dan persyaratan. Sehingga untuk mempermudah pemberian kredit dan tetap sesuai dengan prinsip kehati-hatian maka digunakanlah analisis $5 \mathrm{C}$ dalam setiap penyaluran kredit dan dengan menggunakan analisis 5C pihak KPN Werdhi Yasa dapat mengambil keputusan apakah kredit yang diajukan diterima atau ditolak. Prinsip 5C merupakan prinsip dimana selain dapat membantu kehati-hatian KPN Werdhi Yasa dalam memberikan kredit, prinsip tersebut juga dapat memberikan cara untuk mengetahui sifat atau watak calon debitur, kemampuan calon debitur dalam membayar kreditnya, kondisi kekayaan yang dimiliki calon debitur, prospek usaha calon debitur, dan jaminan yang akan diberikan oleh calon debitur kepada KPN Werdhi Yasa. Berdasarkan latar belakang diatas, maka permasalahan yang dapat dirumuskan yaitu Bagaimanakah Pengaruh Analisis 5C Terhadap Kebijakan Kredit Pada KPN Werdhi Yasa?

\section{Metode Penelitian}

Penelitian ini dibuat untuk memperoleh kejelasan yang berkaitan dengan pemilihan pendekatan yang akan digunakan dalam penelitian untuk memperoleh informasi mengenai pengaruh analisis 5C terhadap kebijakan kredit. Hal yang pertama dilakukan adalah 
menentukan lokasi penelitian dimana penulis melakukan penelitian pada KPN Werdhi Yasa yang beralamat di Jalan Bisma $8 \mathrm{XX}$, Singaraja. Setelah lokasi penelitian ditentukan, peneliti melihat fenomena atau hal-hal seperti apa yang terjadi di KPN Werdhi Yasa, kemudian dari fenomena tersebut dapat dibuat suatu rumusan masalah, setelah dilakukan kajiaan pada teori-teori yang digunakan untuk penelitian ini. Kemudian peneliti mengumpulkan data yang diperlukan untuk penelitian ini. Pengumpulan data yang dilakukan yaitu dengan metode wawancara dan dokumentasi. Data tersebut dianalisis dengan analisis data deskriptif kualitatif. Dari analisis data tersebut peneliti akan mendapatkan hasil penelitian, dari hasil penelitian nantinya dapat dibuatkan kesimpulan dan saran tentang pengaruh analisis $5 \mathrm{C}$ terhadap kebijakan pemberian kredit pada KPN Werdhi Yasa.

\section{Hasil Penelitian dan Pembahasan}

Bagi calon debitur yang ingin mengajukan permohonan kredit pada KPN Werdhi Yasa, calon debitur harus mendapatkan persetujuan dari kepala sekolah tempat calon debitur bertugas, dan apabila calon debitur telah mendapatkan rekomendasi dari pihak kepala sekolah barulah pihak debitur diperkenankan untuk mengajukan permohonan kredit pada KPN Werdhi Yasa. Setelah itu calon debitur datang langsung ke bagian kredit KPN dengan membawa fotocopy KTP dan surat rekomendasi dari kepala sekolah tempat calon kreditur bertugas yang masih berlaku dan menyerahkannya ke bagian kredit KPN Werdhi Yasa, setelah itu bagian kredit KPN akan membuatkan formulir permohonan kredit yang menggunakan data sesuai dengan yang tertera pada KTP. Selanjutnya calon debitur harus mengisi formulir tersebut sesuai dengan data yang tertera pada KTP. Dalam hal ini data-data KTP dari pemohon yang yang digunakan oleh pihak KPN adalah nama, nomor KTP, tempat/tanggal lahir, alamat pemohon, pekerjaan pemohon, jenis kredit, besarnya permohonan kredit, jangka waktu kredit, tujuan pemberian kredit. Contoh calon debitur menginginkan mengambil kredit jangka panjang dengan besarnya permohonan kredit sebesar Rp. 75.000 .000 dengan jangka waktu 120 bulan (10 tahun) dan tujuan kredit untuk membuka usaha toko sembako dirumah calon debitur. Barulah pihak KPN akan melakukan pendataan ke rumah pemohon kredit yang sesuai dengan alamat pemohon yang tertera pada fotocopy KTP.

Tujuan dalam proses pendataan ini adalah untuk mengetahui besarnya jumlah pendapatan selama satu bulan calon debitur serta penghasilan lainnya yang diperoleh, untuk mengetahui besaran pengeluaran calon debitur selama satu bulan seperti biaya air dan listrik, biaya telepon, biaya pendidikan, besar angsuran pinjaman lainnya, untuk mengetahui besarnya aktiva yang dimiliki calon debitur seperti (uang tunai yang dimiliki, simpanan, kendaraan, tanah, bangunan) dan untuk mengetahui pasiva yang dimiliki calon debitur seperti besarnya jumlah pinjaman pribadi dan pinjaman pada bank. Setelah proses pendataan dilakukan maka langkah selanjutnya yang dilakukan oleh KPN Werdhi Yasa adalah melakukan proses analisis berdasarkan data-data yang telah dikumpulkan dari hasil pendataan ke lapangan. Dalam proses analisis kredit yang digunakan oleh pihak KPN Werdhi Yasa yaitu teknik analisis $5 \mathrm{C}$ yang terdiri dari character, capacity, capital, condition of economy, dan collateral. Langkah pertama pihak KPN melihat karakter (character) calon debitur, dari analisis ini pihak KPN akan dapat menyimpulkan apakah calon debitur tersebut memiliki karakter yang baik, jujur dan memiliki keinginan untuk memenuhi kewajiban membayar pinjaman sampai dengan lunas. Dan pada KPN werdhi yasa pihak KPN dapat mengetahui calon debitur berkarakter baik melalui surat rekomendasi berkelakuan baik yang dibuat oleh kepala sekolah tempat calon debitur bertugas. Dari situ pihak KPN berani mengambil keputusan calon debitur memang memiliki karakter yang baik atau tidak. Kemudian kemampuan (capacity) calon debitur dalam membayar kembali kredit yang telah diberikan menjadi bahan pertimbangan KPN, disini pihak KPN melihat dari seberapa besar gaji calon debitur dalam satu bulan dan pertimbangan-pertimbangan lain, seperti biaya kehidupan sehari-hari untuk makan, biaya air, biaya listrik, biaya telpon, biaya pendidikan. Contoh gaji calon debitur sebesar Rp. 4.000.000/bulan, pihak kpn harus mengetahui apakah 
dengan gaji tersebut akan dapat melunasi kreditnya sesuai dengan waktu yang telah ditentukan. Besar pinjaman debitur Rp. 75.000 .000 : waktu pinjaman 120 bulan $=R p$. 625.000 + biaya sehari-hari dalam sebulan sebesar Rp. $1000.000=$ Rp. $1.625 .000,00$ jadi biaya yang akan dikeluarkan oleh si calon debitur perbulan adalah sebesar Rp. 1.625.000 (biaya cicilan kredit perbulan + biaya sehari-hari calon debitur dalam satu bulan) dan dengan gaji Rp. 4.000.000 dalam sebulan, ini yang akan menjadi bahan pertimbangan oleh pihak KPN apakah calon debitur sudah memenuhi poin kemapuan (capacity). Selanjutnya modal (capital) mempengaruhi keputusan bagian kredit dalam memberikan jumlah kredit yang bisa dicairkan. Ini menjadi bahan pertimbangan dengan cara pihak KPN mengetahui bagaimana kondisi kekayaan yang dimiliki calon debitur. Ini dimaksudkan untuk ikut menunjang jumlah kredit yang diinginkan oleh pemohon kredit, bila dikemudian hari kredit yang diberikan kepada pemohon mengalami tunggakan atau mengalami kegagalan kredit. Contoh calon debitur harus memiliki dana cukup dalam mengantisipasi kondisi emergency, untuk wiraswasta harus memiliki cukup aset dan modal untuk mendukung kelancaran usaha serta modal dalam menghadapi masa sepi. Contoh yang bisa dikatakan modal bagi wirausaha, seperti kendaraan, tanah, rumah ruko, surat-surat berharga. Selanjutnya adalah kondisi ekonomi (condition of economy) merupakan analisis terhadap kondisi perekonomian. Pihak KPN perlu mempertimbangkan usaha calon debitur yang dikaitkan dengan kondisi ekonomi, apakah kondisi ekonomi tersebut akan berpengaruh pada usaha calon debitur dimasa yang akan datang. Contoh yang mempengaruhi kondisi ekonomi terhadap prospek usaha calon debitur kedepannya yang menjadi pertimbangan KPN dalam memberika pinjaman, seperti Peraturan pemerintah pusat atau daerah terhadap usaha yang ditekuni calon konsumen, tren industri naik atau turun, Besar dan kecilnya kompetitor yang ada, Kondisi lingkungan tempat tinggal, tempat usaha yang legal atau ilegal. Dan yang menjadi poin terakhir dalam menganalisis kredit adalah poin agunan (collateral) merupakan jaminan yang diberikan oleh calon debiitur atas kredit yang diajukan. Agunan merupakan sumber pembayarann kedua, artinya apabila calon debitur tersebut tidak dapat membayar angsurannya dan termasuk dalam kredit macet, maka pihak KPN dapat melakukan eksekusi terhadap agunan. Yang perlu diperhatikan oleh pihak KPN mengenai jaminan calon debitur adalah nilai jamiinan, minimal nilai jaminan senilai dengan besar kredit yang diajukan oleh pihak debitur. Hasil penjualan agunan digunakan sebagai sumber pembayaran kedua. Contoh calon debitur mengajukan kredit sebesar Rp. 75.000.000. Dan jaminan yang digunakan oleh si calon debitur adalah BPKB mobil yang memiliki nilai jual Rp. 100.000.000. setelah itu pihak KPN memberikan kriteria score kredit yang digunakan dalam analisis kredit pada KPN Werdhi Yasa adalah sebagai berikut : usia pemohon, tingkat pendidikan, alamat, karakter, riwayat hubungan dengan KPN, jaminan. Setelah dilakukannya penilaian score maka pihak KPN Werdhi Yasa akan membuat hasil penilaian dalam formulir analisa kredit yang meliputi : aspek umum, adapun aspek umum yang dimaksud adalah mencantumkan identitas sesuai dengan KTP pemohon seperti nama, nomor KTP, tempat/tanggal lahir, alamat, pekerjaan, besarnya permohonan kredit, jangka waktu kredit dan tujuan permohonan kredit. Setelah itu pihak KPN membuat pernyataan pendapatan dan pengeluaran calon debitur.

Adapun yang dimaksud pernyataan pendapatan dan pengeluaran adalah pernyataan mengenai besarnya jumlah pendapatan selama satu bulan pemohon kredit, serta penghasilan lainnya yang diperoleh, sedangkan pernyataan pengeluaran yang dimaksud adalah mengenai besaran pengeluaran yang dikeluarkan pemohon kredit selama satu bulan seperti biaya air dan listrik, biaya telepon, biaya pendidikan, besar angsuran pinjaman lainya. calon debitur, yang dimaksud adalah laporan keuangan dari pemohon kredit yang meliputi jumlah aktiva dan pasiva yang dimiliki pemohon kredit. Bila analisis telah selesai dilakukan oleh analis kredit KPN Werdhi Yasa selanjutnya pihak analis kredit akan membuat surat pengusulan kredit yang memuat beberapa hal diantaranya sebagai berikut : data pemohon, terdiri dari nama pemohon kredit, nomor KTP pemohon kredit, tempat/tanggal lahir, alamat pemohon kredit, jumlah permohonan kredit, tujuan permohonan kredit. Berdasarkan data yang telah diberikan dan dari hasil analisa permohonan kredit maka dibuatkan rekomendasi 
analisis bagian kredit yang terdiri atas jumlah maksimum kredit yang akan diberikan, suku bunga, jangka waktu, jenis kredit, tujuan penggunaan kredit, nilai jaminan. Selanjutnya dipertimbangkan kepada Tata Usaha KPN Werdhi Yasa yang kemudian diserahkan kepada pemutus kredit yaitu Kepala KPN Werdhi Yasa. Keputusan kredit, Bila proses dari pendataan sampai dengan proses analisis kredit selesai maka selanjutnya pihak KPN membuat surat keputusan kredit atas permohonan kredit yang diajukan oleh pemohon kredit apakah kredit yang diajukan diterima atau ditolak. Bila keputusan kredit menyatakan kredit diterima maka pemohon kredit sudah dapat mencairkan permohonan pinjaman di kasir KPN Wershi Yasa dengan ketentuan akhir yaitu pemohon kredit menandatangani surat perjanjian pinjaman yang disediakan pihak KPN.

Dalam pengambilan keputusan kredit mengenai diterima dan ditolaknya permohonan kredit sangat dipengaruhi dengan analisis $5 \mathrm{C}$ yang diterapkan pada KPN Werdhi Yasa, jadi apabila calon debitur telah lolos dan sesuai dengan karakter, kemampuan, modal, kondisi ekonomi, dan jaminan. Sehingga dapat langsung dipastikan permohonan kredit calon debitur akan diterima oleh KPN Werdhi Yasa. Begitu juga sebaliknya apabila calon debitur tidak lolos dan tidak sesuai dengan kriteria analisis $5 \mathrm{C}$, meskipun kurang hanya satu analisis tapi tetap saja itu yang akan menjadi pertimbangan oleh pihak KPN dan secara langsung permohonan kredit akan ditolak oleh pihak KPN. Mengingat kelima poin tersebut (character, capacity, capital, condition of economy, collateral). Mengingat kelima poin tersebut saling berkaitan dan memang harus kelima poin tersebut harus dimiliki oleh setiap calon debitur. Yang diterapkan oleh KPN Werdhi Yasa untuk meminimalisir terjadinya kredit macet kedepannya.

\section{Simpulan dan Saran}

Berdasarkan hasil penelitian dan pembahasan, maka dapat disimpulkan bahwa analisis 5C sangat berpengaruh terhadap kebijakan kredit pada KPN Werdhi Yasa. Mengingat analisis 5C memang menjadi faktor yang menentukan pada KPN Werdhi Yasa, mengenai diterima atau ditolaknya permohonan kredit yang diajukan oleh calon debitur. Pada KPN Werdhi Yasa, analisis 5C selain dapat membantu kehati-hatian pada KPN Werdhi Yasa dalam memberikan kredit analisis tersebut juga dapat memberikan cara pada KPN Werdhi Yasa untuk mengetahui sifat atau watak calon debitur (character), kemampuan calon debitur dalam membayar kreditnya (capacity), mengetahui kondisi kekeyaan yang dimiliki calon debitur (capital), mengetahui prospek usaha calon debitur kedepannya (condition of economy), dan jaminan yang akan diberikan oleh calon debitur kepada KPN Werdhi Yasa (collateral). Kelima prinsip dalam analisis tersebut telah memberikan keamanan dalam penyaluran kredit oleh KPN Werdhi Yasa, tetapi seluruh prinsip tersebut haruslah dijalankan bersama-sama untuk menghasilkan analisis debitur yang dapat dipertanggung jawabkan.

\section{DAFTAR PUSTAKA}

Catatan Marketing. 2012. Prinsip-Prinsip Pemberian Kredit. Tersedia pada:https://catatanmarketing.wordpress.com/2012/02/11/prinsip-prinsippemberian-kredit/ (diakses tanggal 15 Mei 2016)

Hasibuan. 2008. Dasar-Dasar Perbankan. Cetakan Ketujuh. Jakarta: PT BumiAksara.

Kasmir. 2002. Bank dan Lembaga Keuangan Lainnya. Edisi Revisi 2002. Jakarta: PT. RAJAGRAFINDO PERSADA.

Kementrian Koperasi. 2014. Koperasi Pegawai Negeri Sipil. Tersedia pada : http://kementeriankoperasi.com/koperasi-pegawai-negeri-sipil// (diakses tanggal 10 Maret 2016) 
Pengertian Koperasi. 2016. Pengertian Koperasi Menurut Para Ahli. Tersedia pada:http://www.orangbejo.com/2016/01/10-pengertian-koperasi-menurut-para.html (diakses tanggal 15 Mei 2016)

R.T. Sutantya Rahardja Hadikusuma, 2001. Hukum Koperasi Indonesia. Jakarta : PT Raja Grafindo Persada 